\title{
ПІДВИЩЕННЯ ЯКОСТІ САМОСТІЙНОЇ ПІДГОТОВКИ СТУДЕНТІВ ДО ТЕСТОВОГО КОНТРОЛЮ ЗНАНЬ В УМОВАХ КРЕДИТНО- МОДУЛЬНОЇ СИСТЕМИ
}

О.Я. Попадюк

\author{
ДВНЗ “Івано-Франківський національниймедичний університет”
}

\section{IMPROVING SELF TRAINING OF STUDENTS FOR KNOWELEDGE TESTING IN A CREDIT-TRANSFER SYSTEM}

\section{O.Ya. Popadyuk}

\author{
SHEI "Ivano-Frankivsk National Medical University"
}

\begin{abstract}
У статті описаний спосіб підвищення рівня знань студентів та підвищення ефективності самостійної їх підготовки до тестового контролю шляхом застосування педагогічно-навчальної комп'ютерної програми “Тест-плюс".
\end{abstract}

This article describes how to improve students' knowledge and improve the efficiency of their self-training for test control by applying pedagogical and educational computer software program "Test-plus."

Вступ. На етапі сучасного розвитку освіта переживає процес реформування та становлення. Одним 3 етапів поступального розвитку освіти України $є$ інтеграція у Європейський освітній простір шляхом приєднання до Болонського процесу.

Болонський процес включає в себе здійснення структурного реформування вищої освіти, зміну освітніх програм, форм і методів навчання, контролю й оцінювання навчальних досягнень студента для підвищення якості освіти, можливості випускників вищих навчальних закладів працевлаштуватися на європейському ринку праці [1].

Важливим кроком інтеграції системи освіти України до європейських освітніх структур стала ратифікація Радою Свропи та ЮНЕСКО Конвенції про визнання кваліфікацій, які стосуються вищої освіти в Європейському регіоні. Дана конвенція була підписана представниками 54 держав на конференції у Лісабоні 1997 року. Завдяки даній конвенції стало можливим створення правового поля вищої освіти Свропи та полегшення визнання документів про освіту різних країн [2].

Для України завдання забезпечення якості освіти полягає в збереженніраніше досягнутих позицій вищої школи з одночасним вирішенням завдань орієнтації випускників на задоволення запитів сучасних суспільства і науки.

Для виконання таких завдань сучасна освіта повинна бути конкурентоспроможною, надавати висо- коякісні освітні послуги та якісно реагувати на зовнішні зміни [3].

Згідно 3 підписаною Україною у 2005 році Болонською конвенцією та проведеною реформою вищої освіти в Україні проведено зміни навчального процесу. Згідно зі змінами самостійна робота віднесена до основного виду їх навчальної діяльності студентів. Самостійна робота становить до половини кредитної міри певної дисципліни.

До самостійної роботи студента включено підготовку до вирішення тестових завдань.

Тестування є одним із найсучасніших і науково обгрунтованих методів контролю поточних і підсумкових знань студентів [4].

Враховуючи такі недоліки традиційних іспитів, як: висока організаційна складність, висока трудоємкість робіт, обмежений час перевірки, наявність суб' єктивних та психологічних чинників, чільне місце відводиться системі тестування у сучасному освітьому просторі. Основними функціями тестування є: діагностична (виявлення рівня знань та умінь студента), навчальна (мотивування студента до активації роботи по засвоєнню навчального матеріалу) і виховна (організовує студента до роботи, дисциплінує студента та дозволяє усунути виявлені прогалини у знаннях).

На жаль, рівень підготовки студентів до тестового контролю знань на занятті та підсумковому контролі залишається недостатнім. Для проведення тестово-

() О. Я. Попадюк 
го контролю все частіше застосовують комп'ютерне програмне забезпечення. Проведений нами огляд даних літератури засвідчив про стрімкий розвиток та впровадження програмного забезпечення у систему освіти, але недостатню кількість програм для проведення тестування студентів-медиків [5, 6].

Саме для підвищення рівня самостійної підготовки студентів та забезпечення виконання виховної, діагностичної та навчальної функцій тестування за допомогою комп'ютерного програмування нами пропонується нова навчально-педагогічна комп'ютерна програма “Тест плюс".

Основна частина. Навчально-педагогічна комп'ютерна програма “Тест плюс” написана на мові програмування "Borland C++6", не потребує інсталяції, займає мало місця на жорсткому диску та легка у користуванні. Дана програма працює від Winows 98 до сучасної Windows 8 і не потребує жодних додаткових допоміжних програм.
Питання та відповіді формуються у файлі *.txt формату. Програма “Тест плюс" призначена для підвищення рівня підготовки студентів до тестування шляхом застосування підказок до тестових завдань при їх вирішенні.

Після запуску програми на екрані з' являється вікно з назвою програми, їі авторами. В окремих виділених віконечках потрібно вибрати тестові завдання до певної теми заняття, ввести прізвище виконавця тестів та потрібну кількість тестових завдань, яка буде ним вирішуватись (рис. 1). Програма включає можливість вибору часу, виділеного для вирішення завдань, що є важливим при тренуванні студента та забезпечує часові параметри, наближені до екзаменаційних.

Після заповнення прізвища та ім'я виконавця, вибору кількості питань та їх тематики студент переходить безпосередньо на сторінку тестування (рис. 2).
Puc. 1. Стартова сторінка комп'ютерної програми "Тест плюс".

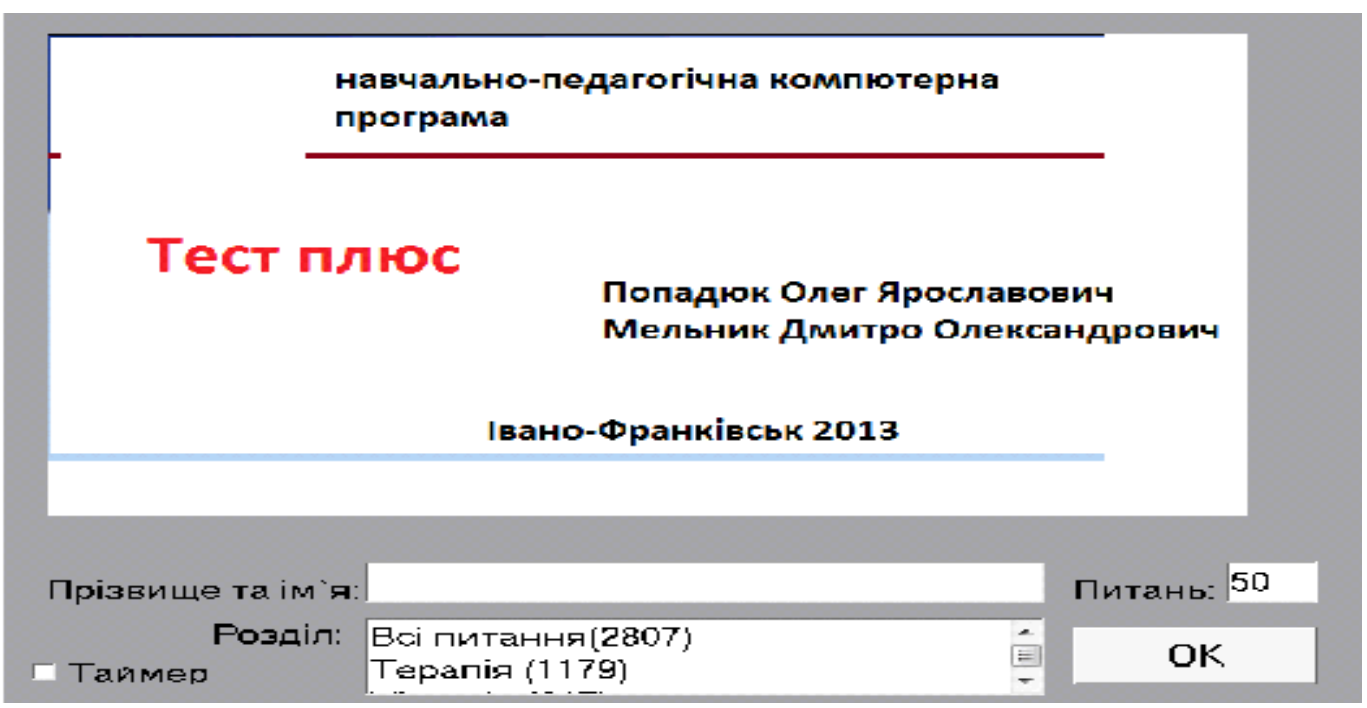

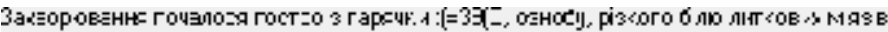

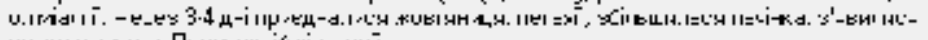

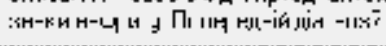

1. Uірусний гепэти.

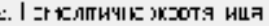

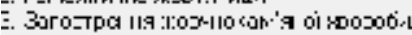

1. varaps

E. . Terrocip:s.
Puc. 2. Сторінка 3 тестами та варіантами відповідей. 
Особливістю даної програми є те, що запропоновані студенту відповіді перемішуються програмою без втручання ззовні, що забезпечує розміщення правильної відповіді під різними номерами при кожному старті програми користувачем.

Якщо виконавець вибрав неправильну відповідь, тоді програма надає підказку, навідну інформацію сту- денту та можливість повторно відповісти на питання. У випадку повторної неправильної відповіді студент отримає "0" балів та має можливість відповідати на наступне запитання (рис. 3).

Підказки завчасно вводяться до комп'ютерної програми на вибір викладача. По закінченні тестування студент отримує інформацію про кількість неправиль-

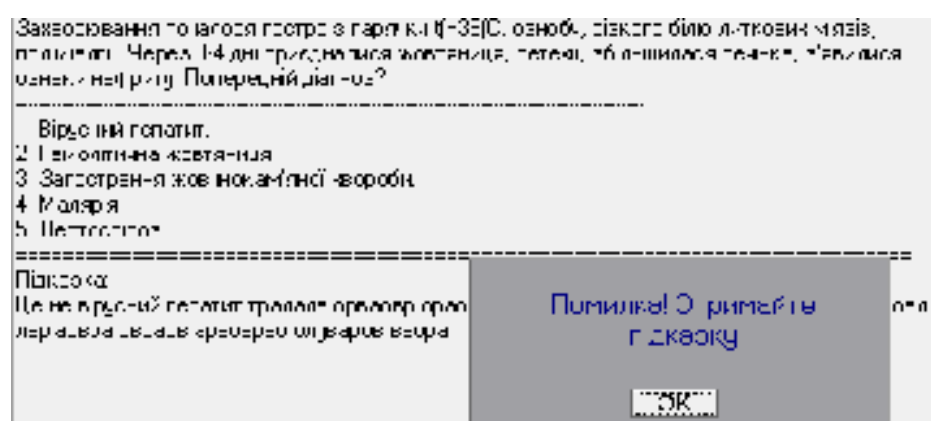

Puc. 3. Вікно програми з підказкою. них відповідей, кількість правильних відповідей та затрачений час. Це дає можливість вибрати кількість часу для проходження тестування та скорегувати кількість питань.

Усі результати тренування студента знаходяться в окремій папці, доступ до якої дозволяє проаналізувати процес навчання та отримані помилки, тенденцію до покращення.

Висновки. Запропонована навчально-педагогіч-

\section{Література}

1. Фомін П. Д. Впровадження болонського процесу у реформуванні навчально-методичних підходів на кафедpax хірургії / П. Д. Фомін, П. В. Іванчов, О.В.Заплавський // Медична освіта. - 2013. - № 2. - С. 96-98.

2. Каленюк I. Рух Свропи до суспільства знань. Болонський процес і Україна / I. Каленюк, К. Корсак // Вища освіта України. -2004. -№3.-С. 22-27.

3. Нагірний Я. П. Болонський процес і забезпечення якості освіти / Я. П. Нагірний // Фармацевтичний часопис. 2011. -№ 1. - С. 74-77.

4. Семестрові комплексні тестові іспити - надійний критерій оцінки знань студентів / І. Р. Мисула, В. П. Марценюк, на комп'ютерна програма “Тест плюс” дозволяє підвищити рівень підготовки студентів до вирішення тестових завдань, підвищити рівень їх знань завдяки наданій можливості обробки, аналізу отриманих підказок. Саме надані підказки та навідна інформація у тесті дозволяють розвивати у студента аналітичне й логічне мислення, тим самим підвищуючи рівень самостійної підготовки студентів до аудиторного тестового контролю.

К. О. Пашко, О. О. Стаханська // Медична освіта. - 2010. - № 1.- С. 16-17.

5. Фуштей І. М. Використання комп'ютерних систем оцінки знань “Крок-2 та 3” упіслядипломному навчанні лікарів на кафедрі клінічної лабораторії діагностики Запорізького державного інституту удосконалення лікарів, / І. М. Фуштей, Л. Л. Воронцова, О. С. Семенцов // Мед. освіта. - 2003. -№ 2. - C. 20-22.

6. Марценюк В. П. Впровадження у навчальний процес комп'ютерних технологій / В. П. Марценюк // Мед. освіта. -2007. - № 2. - C. 40-42. 